\title{
MARKET SUPPLY RESPONSE OF IMPORTED SARDINELLA IN CROSS RIVER STATE, NIGERIA
}

E. A. ETUK, I .A. ISANGEDIGHI, AND D. S. UDOM

(Received 22, January 2010; Revision Accepted 6, July 2010)

\begin{abstract}
This study was carried out to determine the market supply response of imported frozen sardinella in Cross River State, Nigeria. Secondary data used for the study were obtained from the records of the five wholesale companies in Cross River state. Cointegration and error correction models were used in analyzing market supply response. The following results were obtained; the short-run and long-run own price elasticity were 2.062 and 1.257 which were significant at the 5 percent and 1 percent levels respectively. The error correction coefficient Ect(-1) was 1.536 which was significant at the 5 percent level. The own price long-run elasticity estimates were in accordance with a priori expectations. Adjustment from short-run towards long-run equilibrium was achieved instantaneously. Consequently, short-run elasticity estimates were found to be larger than those of the long-run. This study recommends the provision good distribution network to avert distortions in supply.
\end{abstract}

KEY WORDS: Market Supply, Cointegration, Short Run, Long Run, Price Elasticity,

\section{INTRODUCTION}

Fish, as a food item, has been recognized for many years to contribute greatly to the dietary needs of Nigerians. As a source of protein, fish holds the promise of reducing protein deficiency in the country since all food nutrients except carbohydrates are known to be present in fish (Ukoha, 1998). With a population of 140 million persons in 2006 and a population growth rate of 2.9 per cent per annum coupled with an attendant increase in rural-urban migration, imported fish consumption has been on the increase. Nigeria remains a major importer of fish because the sources of domestic fish production in Nigeria can barely meet the widening gap between domestic demand and production (supply). It is relevant to note that Nigeria's domestic market supply in 2003. (Global Agriculture Information Network, 2004).

Frozen seafood imports are widely distributed in the country, through a network of privately owned cold stores located in major cities. The frozen seafood is available in city markets, and also smoked for rural village markets. The wholesaler is the nucleus of distribution channel in Nigeria's retail sector and serves nearly every member in the distribution channel (Nigeria Fish Organization, 2006). There are various species of fish imported into Nigeria namely; herrings, horse mackerel, croaker, sardinella and mackerel. These species are sold in Cross River State, Nigeria. With the ban on importation of frozen poultry products in July 2002 , fish given its relatively cheaper cost has become fishing activities contributed only 13 percent of total

human food, livestock feed, source of income, part of healthy diet and an important employer of labour.

Most studies done in the area of fishery subsector in Nigeria have been on the demand of the commodity. For instance, Fabiyi (1983), Aderinola and Adesimi (1983), Fatunla et al., (1987), Ladipo et al.,(1987). In the area of domestic supply response, Etuk et al., (2003) reported that the own prices of fish was the single most important determinant of output. These studies either econometric or theoretical used either static or Nerlovian approaches to estimate static or dynamic specification of supply response using Ordinary Least Squares (OLS). The supply response estimates obtained from previous studies may have provided spurious results due to the use of OLS on non-stationary time series data.

Therefore, this study uses a more recent time series technique of Cointegration and Error Correction to study the market supply response of imported sardinella in Cross River State.

\section{THE DATA}

This study used secondary data. These data were obtained from the records of purposively selected major imported fish companies in of Cross River State.

Monthly wholesale sale price $(\mathrm{N} / 25 \mathrm{~kg})$ of

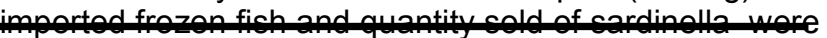
E. A. Etuk, Department of Agricultural Economics, University of I.A. Isangedighi, Department of Agricultural Economics, Uni(yesityany C logarithmic

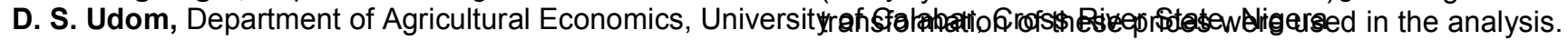
the major source of protein for the people of Nigeria, and indeed Cross Riverians majority of who fall under the low income bracket. (Moses,1980).

In Cross River State, $80 \%$ of the available animal protein comes from fish and fish products, Moses (1980). Imported fish remains an important source of An aggregation of data from five major imported fish companies were used for this study. Of these, three companies (A,B and $\mathrm{C}$ ) are located in Calabar Municipality while two companies (D and $E$ ) are located in Calabar south local government area. These two local government areas serve as the central dispersal wholesale market for frozen fish in Cross River State 


\section{METHODOLOGY}

Following Lipsey and Steiner (1981) on the determinants of supply, we assume a first order autoregressive process. We specify an implicit function thus;

$Q_{\mathrm{t}} \quad-\quad \alpha_{0}+\alpha_{1} P_{0}+\alpha_{2} P_{\mathrm{i}}+E_{\mathrm{t}}$ Where;

$Q_{t} \quad$ - $\quad$ Selling quantity of imported frozen sardinella.(25kg/carton)

$\alpha_{0} \quad$ - $\quad$ Constant term

$\alpha_{1} \quad-\quad$ Own price elasticity coefficient

$\mathrm{P}_{0} \quad$ - $\quad$ Own price of imported frozen sardinella.(N)

$\alpha_{2} \quad$ - $\quad$ Price of other species elasticity coefficient

$\mathrm{Pi} \quad$ - $\quad$ Prices of other species of imported frozen fish ( $\mathrm{N}$ )

Et $\quad$ - $\quad$ The stochastic error term with the usual assumptions.

Many economic time series are non-stationary and in general OLS regressions between non-stationary data are spurious. (Banerjee et.al,1993). The presence of a unit root in the autoregressive representation of a time series leads to non stationarity. This will lead to spurious regressions if a stationary co-integrating relationship is not established between the variables. Since con-integration is a precondition for the specification of an Error Correction Model (ECM), we begin by testing for the presence of unit root in the individual time series using the Augmented Dickey-Fuller (ADF) test (Dickey and Fuller, 1981). The lag length in the co-integrating equation is chosen using the Johansen procedure (Johansen, 1988), the tests (trace and Maximum-eigenvalue) indicates whether the data series are co-integrated and have one co-integrating equation at the 0.05 level. Thereafter an Error Correction Model (ECM) is specified for the endogenous series of quantity, own price and prices of other species as shown below

$\Delta \mathrm{Q}_{\mathrm{t}}=\alpha_{10}+\alpha_{11}+\Delta \mathrm{P}_{0 \mathrm{t}}+\alpha_{12} \Delta \mathrm{Q}_{\mathrm{t}-1}+\alpha_{13} \Delta \mathrm{Q}_{0 \mathrm{t}-1}+\alpha_{14}\left(\mathrm{Q}_{\mathrm{t}-1}-\mathrm{P}_{0 \mathrm{t}-1}\right)+\mathrm{E}_{\mathrm{t} 1}$

$\Delta \mathrm{P}=\alpha_{20}+\alpha_{21} \Delta \mathrm{P}_{\mathrm{it}-1}+\alpha_{22} \Delta \mathrm{Q}_{\mathrm{t}-1}+\alpha_{23}\left(\mathrm{Q}_{\mathrm{t}-1}-\mathrm{P}_{\mathrm{it}-1}\right)+\mathrm{E}_{\mathrm{t} 1}$

Where $\alpha_{14}$ and $\alpha_{23}$ represent the error correction mechanism (coefficient)

$\mathrm{Q}_{\mathrm{t}-1}-\mathrm{P}_{\mathrm{it}-1}$ is the correction term

$E_{t 1}$ and $E_{t 2}$ are stochastic error terms assumed to be white noise.

$\Delta$ is the first difference operator

In long-term equilibrium, the error correction term is zero. However, if $Q_{t}$ and $P_{0}$ deviate from the long-run steady -state equilibrium, the error correction term will be non -zero and each variable adjusts to partially restore the equilibrium relation. The error correction coefficient measures the speed of adjustment of the $i^{\text {th }}$ endogenous variable towards the static long-run equilibrium.

On a priori grounds the variables $\alpha_{11}, \alpha_{13}, \alpha_{22}$, are expected to be positive while the variable $\alpha_{21}$, is expected to be indeterminate.

RESULTS AND DISCUSSION

TABLE 1.0

Johansen cointegration test for supply of sardinella

\begin{tabular}{llllll}
\hline $\begin{array}{l}\text { Hypothesize } \\
\text { No. of CE(s) }\end{array}$ & Eigen Value & $\begin{array}{l}\text { Trace } \\
\text { Statistics }\end{array}$ & $\begin{array}{l}\mathbf{0 . 0 5} \\
\text { Critical } \\
\text { Value }\end{array}$ & $\begin{array}{l}\text { Max-Eigen } \\
\text { Statistics }\end{array}$ & $\begin{array}{l}\mathbf{0 . 0 5} \\
\text { Critical } \\
\text { Value }\end{array}$ \\
\hline None* & 0.5254 & 132.6983 & 95.7537 & 78.2590 & 40.0776 \\
At most 1 & 0.2411 & 54.4393 & 69.8189 & 28.9644 & 33.8769 \\
At most 2 & 0.086060 & 25.4749 & 47.8561 & 9.4490 & 27.5843 \\
At most 3 & 0.08450 & 16.0260 & 29.7971 & 9.2700 & 21.1316 \\
At most 4 & 0.0340 & 6.7559 & 15.4947 & 3.6277 & 14.2646 \\
At most 5 & 0.0299 & 3.1282 & 3.8415 & 3.1282 & 3.8415 \\
\hline
\end{tabular}

Trace test and Max-eigenvalue test indicates 1 cointegrating equation at the 0.05 level

* denotes rejection of the hypothesis at the 0.05 level

From the result presented in Table 1.0, it is evident that both the trace and maximum eigenvaalue test indicates one cointegration equation each, as the null of no cointegration is rejected. . Since the variables are cointegrated, the VEC estimates presented in Table 2.0 will not be spurious regression estimates .We therefore conclude that there is unique long-run equilibrium relationship between the aggregate quantity of sardinella supplied in all firms, its own price and the price of other species. Our cointegrating coefficients normalized on the quantity

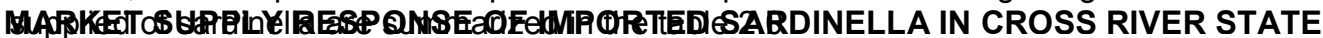

TABLE 2.0

\begin{tabular}{cll} 
Error Correction Model Estimates for sardinella supply for the companies \\
\cline { 2 - 3 } Variables & $\begin{array}{l}\text { Explanatory variables } \\
\text { short run }\end{array}$ & $\begin{array}{l}\text { Explanatory } \\
\text { variables } \\
\text { long run }\end{array}$ \\
\hline Constant. & -0.0012 & -0.02191 \\
& $(-0.2012)$ & 1.2567 \\
Sardinella & 2.0618 & $(4.0024)^{\star * *}$ \\
\hline
\end{tabular}




\begin{tabular}{lll}
\hline croaker & 0.9020 & 1.5580 \\
herrings & $(0.9277)^{\mathrm{NS}}$ & $(2.7985)^{* *}$ \\
& -0.3842 & -0.8070 \\
Horse & $(-0.5716)^{\mathrm{NS}}$ & $(-2.2377)^{\star *}$ \\
mackerel & 1.0047 & 1.0138 \\
Tariff rate & $0.1051)^{\mathrm{NS}}$ & $(1.8902)^{\star}$ \\
& $(1.75177)^{\star}$ & 0.0269 \\
EC $_{\mathrm{t}}(-1)$ & -1.5368 & $(0.4653)^{\mathrm{NS}}$ \\
$\mathrm{R}^{2}$ & $(-2.1398)^{\star *}$ & \\
Adjusted $\mathrm{R}^{2}$ & 0.9729 & \\
F-Statistic & 0.8873 & \\
Akaike AIC & 11.3674 & \\
LM- $\chi^{2}$ & -2.7448 & \\
\hline
\end{tabular}

Note: figures in parenthesis are t-statistics *,**,*** indicates significant at $10 \%, 5 \%$ and $1 \%$ level respectively. NS indicates not significant

In the short run, the aggregate price elasticity of sardinella for all the firms is 2.0618 which is significant at the $5 \%$ level while in the long run; the aggregate price elasticity of sardinella is 1.2567 and is significant at the $1 \%$ level. Both co-efficient are elastic. This suggests that a $1 \%$ increase in the price of sardinella will lead to an increase in the quantity of sardinella supplied by $20.62 \%$ and $12.57 \%$ in the short run and long run respectively. This result also implies that the speed with which the price of sardinella adjusts from short run to long run equilibrium is instantaneous. This explains why the short run elasticity estimate is larger than the long run estimate

For the prices of other species, in the short run, the aggregate price elasticity of croaker is 0.9020 in the short run and is not significant while in the long run, the price elasticity is 1.5580 and is significant at the $5 \%$ level. Both coefficients are elastic. The implication here is that a $10 \%$ increase in the price of croaker would cause the quantity supplied of sardinella to increase $15.58 \%$ in the long run.

Herrings price elasticity is -0.3842 in the short run and is not significant while in the long run, its price elasticity in -0.8070 and significant at the $5 \%$ level. Both estimates are elastic. The implication here is that a $10 \%$ increase in the price of herrings will lead to a $3.84 \%$ and an $8.07 \%$ decrease in the quantity supplied of sardinella in the short run and long run respectively.

Horse Mackerel price elasticity is 1.0047 in the short run and 1.0138 in the long run. The long run price elasticity is significant at the $10 \%$ level. This implies that a $10 \%$ increase in price of horse mackerel would cause

the quantity supplied of sardinella to increase by $10.13 \%$ in the long run.

The tariff rate coefficient of 0.1051 in the short run was significant at the $10 \%$ level while the coefficient of 0.0269 obtained for the long run was not significant. The implication here is that the reduction in the import tariff rate for frozen fish from $25 \%$ to $5 \%$ by the government changed supply conditions in the market immediately.

The error correction co-efficient (-1.5368), which measure the speed of adjustment towards long run equilibrium carries the expected negative sign and is significant at the $5 \%$ level. The co-efficient indicates a feedback of about $153.68 \%$ to the previous month's disequilibrium from the long run elasticity of the price of sardinella. This implies that the speed with which the price of sardinella adjusts from short run disequilibrium to changes in quantity supplied in order to attain long run equilibrium is $153.68 \%$ in less than one month. This is very high and signals an overreaction of the quantity supplied of sardinella as a result of changes in price.

\section{CONCLUSION}

With the market supply response of Sardinella being own price elastic, the overall implication is that the continued contribution of this specie as one of the cheapest source of protein for Cross Riverians could be quite substantial under circumstances that help improve the market supply/availability of this commodity. On the strength of this, this paper recommends the provision improved road network and the use of mobile cold trucks in product transportation to help reduce cost and prevent loss due to spoilage thereby checking distortions in supply.

50

E. A.

\section{REFERENCES}

Aderinola, E. A. and A. A. Adesimi., 1983.Economic Analysis of Fish Import Demand".Fisheries Society of Nigeria Conference Proceedings. FISON, 159-169.

Banejee, A., J. Dolado, J. Globriath and D. Hendry., 1993, Co-integration, error correction and econometric analysis of non-stationary data, Oxford: oxford University Press. In: McKay, A., Oliver $M$ and Charlotte, V. (2003). Aggregate export and Food crop Supply Response in Tanzania. Credit Research Paper 98/4, 1-22.

Dickey, D. A., Fuller W. A., 1981. Likelihood ratio statistics for autoregressive time series with a unit root. Econometrica 49, 1057-1072

Etuk, E. A., Udom, D. S., and Isangedighi, I. A., 2003. Supply response of selected fished in Nigeria (1980-1998). Nigerian Southeast Journal of Agricultural Economics and Extension, 5, 85-95.

Fabiyi, Y. I., 1983. "Demand for fish in Calabar, Cross River State, Nigeria" Proceedings of Fishery Society of Nigeria. FISON, 62-69. 
Fatunla, G. T., O. L. Oladimu, O. O. Ladipo., 1987. “ A Quantitative analysis of demand for fish in Nigeria". Proceedings of the fishery society of Nigeria. FISON, 201-206.
Ukoha, O. O., 1998. "The fishery sub-sector in Nigeria; An analysis of the output performance and the way forward". In: Agricultural development in the $21^{\text {st }}$ century -concept and strategies. FAMAN, Abubakar Tafewa University, Bauchi.

Global Agricultural information Network (GAIN) (2004). Nigerian product brief: The Nigerian seafood brief (update) 2004. USDA foreign agricultural service (unclassified). Lagos, Nigeria. N14012,1-11.

Johansen, S., 1988. Statistical analysis of co-integrating vectors. Journal of economic dynamic and control 12:231-254. :In co-integration and error correction modeling of agricultural commodity trade. The case of ASEAN agricultural export to the E. U. (2003). Agricultural and Food Science in Finland 12,103.

Ladipo, O. O., O. Saniake, O. L., Oludimu., 1987. "A Statistical investigation of fish prices in Nigeria. Conference proceedings of the fishery society of Nigeria, FISON, 207-217.

Lipsey, R. G. and Steiner, P. O., 1981 Economics, sixth edition, Harper Row Publishers, New York.

Moses, B. S., 1980. "Fishers of the Cross River State of Nigeria", Bulletin of Fisheries Division Ministry of Agriculture and Natural Resources, Calabar, Nigeria.

Nigeria Fish Organization (2006). Fish Report Retrieved from www, nigeriafish.org on $22^{\text {nd }}$ Nov. 2006. 

